\title{
General practice workload and certification of illness during a coalfield strike
}

\author{
J. E. LUNN, J. G. RIDER, W. H. R. WATERS, and R. B. CHARNOCK \\ Department of Preventive Medicine, University of Sheffield and Hatfield and Dunscroft \\ General Practice
}

Lunn, J. E., Rider, J. G., Waters, W. H. R., and Charnock, R. B. (1970). Brit. J. industr. Med., 27, 368-371. General practice workload and certification of illness during a coalfield strike. During a two-week coalfield strike the miners in the study practice demanded less medical attention and required fewer certificates than usual. These findings contrasted with the picture for the non-miners which showed no change.

The Hatfield Dunscroft Practice cares for some 10,500 patients, most of whom live in the Hatfield Parish of Thorne Rural District in the Yorkshire West Riding. The 1966 Sample Census for the Parish records a total population of 13,580 persons. The working males number 4,090 , of whom 1,010 are engaged in mining and 3,080 in other occupations. Nearly all the mining workers are employed at Hatfield Main Colliery.

Studies have already been carried out in the Practice to measure workload and sickness certification rates (Rider, Waters, Charnock, and Lunn, 1969; Lunn, Rider, Waters, and Charnock, 1970). Consequently the collection of this type of information has become a standard procedure which can be started up at short notice and the Practice was able, therefore, to look at workload and sickness certification when the area was affected by the recent mining industry strike.

On Saturday, 11 October 1969, the Yorkshire Area Council of the National Union of Mineworkers (NUM) recommended to all Yorkshire branches that they should strike from Monday, 13 October 1969.

On Monday, 13 October 1969, all work carried out by NUM members (except safety work) ceased at Hatfield Main Colliery and at the surrounding collieries.

The Yorkshire Area Council of the NUM at a meeting on Saturday, 25 October 1969, recommended a return to work, and normal working began at
Hatfield Main and the other local collieries on Monday, 27 October 1969. Although the strike was recommended by the Area Council, it was regarded as unofficial by the central organization of the NUM and no strike pay was given out. Dependents were, of course, entitled to supplementary benefits, but these made up only a small proportion of the wages lost.

The collection of information started at midnight on the second day of the strike and continued for 19 days. This period covered the remaining 12 days of the strike and the first 7 days of the return to work. It would have been better to have collected information from the first day of the strike but this was not considered possible because one of the three partners was absent. Consequently it seemed unlikely that the remaining two would be able to cope with the expected increase in workload as well as ill out forms for each consultation. Within 24 hours there was a strong subjective impression that the workload had decreased rather than increased and it was decided to go ahead with the collection of information as soon as the third partner returned.

All National Insurance (NI) certificates were recorded and were classified according to the procedure defined by Carne (1969) into 'first', 'intermediate', and 'final' certificates. In addition a 'first and final' type of certificate was recorded indicating a single NI certificate covering a short complete episode of illness.

Information from the Practice was already avail- 
able for five 'runs' of one week each in November 1968 and February, April, June, and September 1969. These data are presented for comparison with the strike data.

\section{Findings}

Details of consultations and NI certificates issued are shown in Table 1. Although the miners number only a quarter of the working males, they produced just over half of the workload and required well over half of the certificates during the five pre-strike 'runs'. The total numbers of consultations required by miners and non-miners were 897 and 882 respectively, and the numbers of certificates were 806 and 591.
During the strike 'run' the miners required less than half of the consultations and certificates. The picture is shown in Figures 1 and 2.

Table 2 shows the types of NI certificates issued. The strike 'run' shows a marked drop in the number of 'first' certificates and a drop also in the number of 'final' certificates issued to miners. These figures show that the miners in this practice were not attempting to obtain benefit by feigning sickness, indeed they made less demand than usual. The figures also suggest that those miners already receiving sickness benefit continued to do so when there was no job to return to. The move to sign off appears in the post-strike 'run' as a rise in 'final' certificates. It is of interest to note that the highest proportion of miners' consultations at which no certificate was

TABLE 1

Consultations and Certificates over 'Runs' of One Week (Miners and Non-miners)

\begin{tabular}{|c|c|c|c|c|c|c|c|c|c|c|c|c|c|}
\hline & & & & & & & & \multirow{2}{*}{\multicolumn{3}{|c|}{$\frac{\text { Miners' consultations }}{\text { Certificates given }}$}} & \multirow{2}{*}{\multicolumn{3}{|c|}{$\frac{\text { Non-miners' consultations }}{\text { Certificates given }}$}} \\
\hline & & \multicolumn{6}{|c|}{ 'Run' dates } & & & & & & \\
\hline & & & & & & & & No & Yes & Total & No & Yes & Total \\
\hline $\begin{array}{l}\text { November } 1968 \\
\text { February } 1969 \\
\text { April } 1969 \quad \ldots \\
\text { June } 1969 \quad \ldots \\
\text { September } 1969\end{array}$ & $\begin{array}{l}\cdots \\
\cdots \\
\cdots \\
\cdots \\
\cdots\end{array}$ & $\begin{array}{l}\cdots \\
\cdots \\
\cdots \\
\cdots \\
.\end{array}$ & $\begin{array}{l}\cdots \\
\cdots \\
\cdots \\
\cdots \\
.\end{array}$ & $\begin{array}{l}\cdots \\
\cdots \\
\cdots \\
\cdots\end{array}$ & $\begin{array}{l}\ldots \\
\ldots \\
\cdots \\
\cdots\end{array}$ & $\begin{array}{l}\ldots \\
\ldots \\
\cdots \\
\ldots\end{array}$ & $\begin{array}{l}\ldots \\
\cdots \\
\cdots \\
\ldots\end{array}$ & $\begin{array}{l}26 \\
23 \\
17 \\
12 \\
13\end{array}$ & $\begin{array}{l}151 \\
168 \\
138 \\
156 \\
193\end{array}$ & $\begin{array}{l}177 \\
191 \\
155 \\
168 \\
206\end{array}$ & $\begin{array}{l}62 \\
47 \\
56 \\
65 \\
61\end{array}$ & $\begin{array}{r}122 \\
144 \\
91 \\
96 \\
138\end{array}$ & $\begin{array}{l}184 \\
191 \\
147 \\
161 \\
199\end{array}$ \\
\hline $\begin{array}{l}\text { Strike October } 1 \\
\text { First week (5 } \\
\text { Second week }\end{array}$ & & $\begin{array}{l}\ldots \\
\ldots\end{array}$ & $\begin{array}{l}\ldots \\
\ldots\end{array}$ & $\begin{array}{l}\ldots \\
\ldots\end{array}$ & $\begin{array}{l}\cdots \\
\ldots\end{array}$ & $\begin{array}{l}\cdots \\
\ldots\end{array}$ & $\begin{array}{l}\cdots \\
\ldots\end{array}$ & $\begin{array}{l}26 \\
36\end{array}$ & $\begin{array}{r}96 \\
112\end{array}$ & $\begin{array}{l}122 \\
148\end{array}$ & $\begin{array}{l}43 \\
63\end{array}$ & $\begin{array}{r}99 \\
128\end{array}$ & $\begin{array}{l}142 \\
191\end{array}$ \\
\hline \multicolumn{5}{|c|}{ Post-strike week (October-November 1969) } & . & . & . & 21 & 129 & 150 & 62 & 127 & 189 \\
\hline
\end{tabular}

TABLE 2

Types of Certificate Issued over 'Runs' of ONe Week (Miners and Non-miners)

\begin{tabular}{|c|c|c|c|c|c|c|c|c|c|c|c|c|}
\hline \multicolumn{5}{|c|}{ 'Run' dates } & \multicolumn{4}{|c|}{ Miners } & \multicolumn{4}{|c|}{ Non-miners } \\
\hline & & & & & First & Intermediate & Final & $F$ and $F$ & First & Intermediate & Final & $F$ and $F$ \\
\hline $\begin{array}{ll}\text { November } 1968 \ldots \\
\text { February } 1969 \ldots \\
\text { April } 1969 & \ldots \\
\text { June } 1969 & \ldots \\
\text { September } 1969 & \ldots\end{array}$ & $\begin{array}{l}\cdots \\
\cdots \\
\cdots \\
\cdots \\
\cdots\end{array}$ & $\begin{array}{l}\cdots \\
\cdots \\
\cdots \\
\cdots \\
\cdots\end{array}$ & $\begin{array}{l}\cdots \\
\cdots \\
\cdots \\
\cdots \\
\cdots\end{array}$ & $\begin{array}{l}\cdots \\
\cdots \\
\cdots \\
\cdots\end{array}$ & $\begin{array}{l}37 \\
39 \\
31 \\
35 \\
45\end{array}$ & $\begin{array}{l}58 \\
57 \\
54 \\
63 \\
98\end{array}$ & $\begin{array}{l}41 \\
48 \\
38 \\
45 \\
42\end{array}$ & $\begin{array}{r}15 \\
24 \\
15 \\
13 \\
8\end{array}$ & $\begin{array}{l}33 \\
47 \\
19 \\
31 \\
40\end{array}$ & $\begin{array}{l}41 \\
39 \\
32 \\
32 \\
40\end{array}$ & $\begin{array}{l}37 \\
41 \\
29 \\
26 \\
42\end{array}$ & $\begin{array}{r}11 \\
17 \\
11 \\
7 \\
16\end{array}$ \\
\hline $\begin{array}{l}\text { Strike October } 1969 \\
\text { First week (5 days) } \\
\text { Second week .. }\end{array}$ & $\begin{array}{l}. \\
\ldots\end{array}$ & $\begin{array}{l}\cdots \\
\cdots\end{array}$ & $\begin{array}{l}. . \\
.\end{array}$ & $\begin{array}{l}\ldots \\
\ldots\end{array}$ & $\begin{array}{l}12 \\
13\end{array}$ & $\begin{array}{l}66 \\
76\end{array}$ & $\begin{array}{l}14 \\
21\end{array}$ & $\begin{array}{l}4 \\
2\end{array}$ & $\begin{array}{l}32 \\
30\end{array}$ & $\begin{array}{l}26 \\
49\end{array}$ & $\begin{array}{l}29 \\
35\end{array}$ & $\begin{array}{l}12 \\
14\end{array}$ \\
\hline Post-strike week (Octo & & 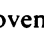 & 1969) & & 15 & 67 & 40 & 7 & 22 & 50 & 36 & 19 \\
\hline
\end{tabular}

$F$ and $F=$ first and final. 

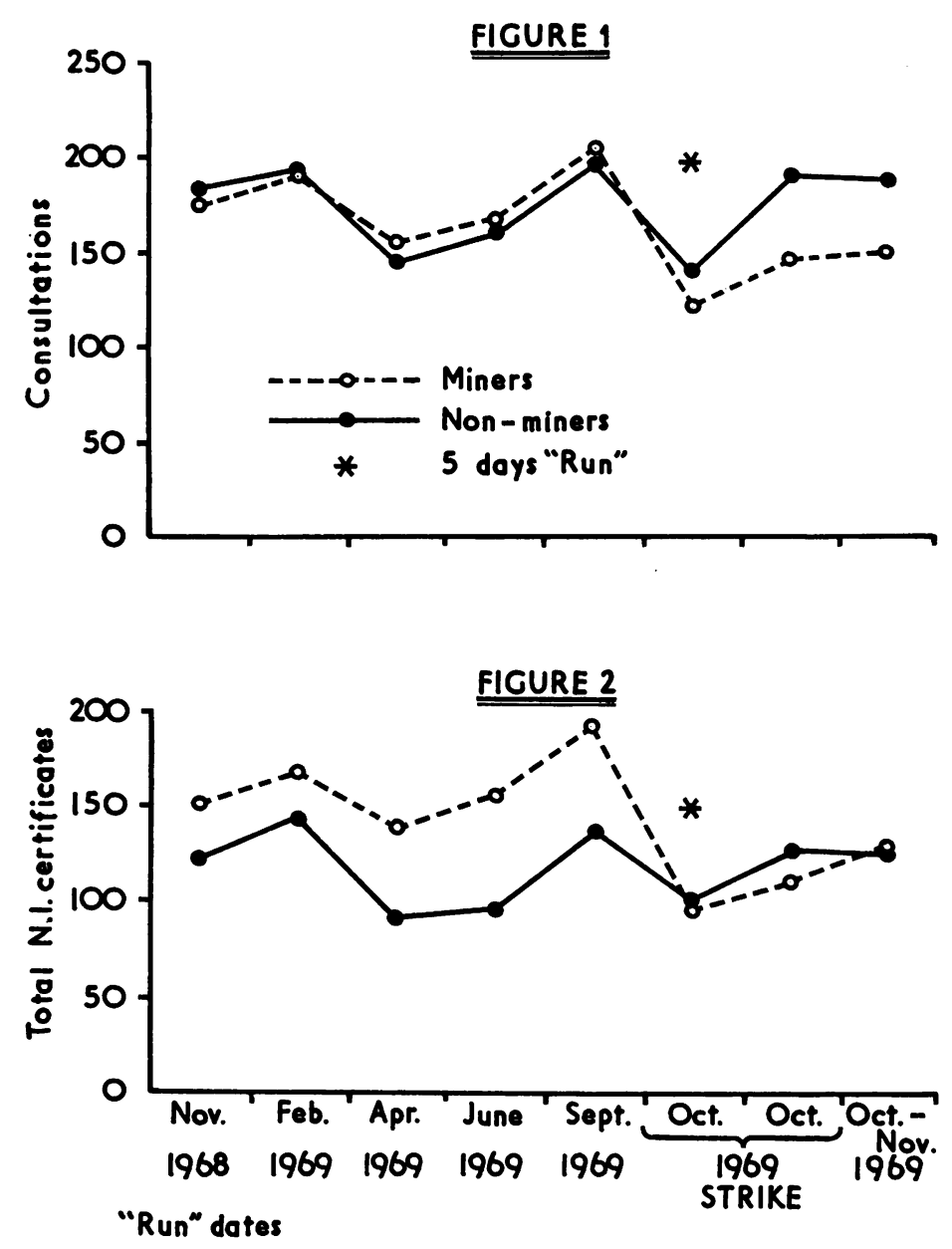

FIG. 1. Total number of consultations by miners and nonminers ('runs' of one week).

FIG. 2. Total number of NI certificates given to miners and non-miners ('runs' of one week). issued occurred during the strike 'run' $\left(\frac{62}{270}=23 \%\right)$.

The next highest figure occurred in the November 1968 'run' $\left(\frac{26}{177}=15 \%\right)$.

\section{Discussion}

The practices of men in choosing sickness or unemployment benefit as an alternative to wages is a vexed question, argued more frequently on subjective than objective data. Taylor and Pocock (1969) suggest that changes in the levels of unemployment experienced in Great Britain in the past two decades have not significantly influenced the rates of certified incapacity for work and attribute this to the comparatively high benefits available. On the other hand, the readiness of some people to rely on generous benefits is reported by the Department of Health and Social Security (1969) who recorded that, of a sample of 11,000 men unemployed for at least three months, 6 out of 10 ceased to draw allowances before, or soon after, they were interviewed on the subject of their unemployment. Consequently one might expect that in a strike situation, which prevented men from receiving wages or unemployment benefit, there might well be a move into sickness benefit (Fay, 1969; Stevenson, 1969).

All we can say here is that the miners in the Hatfield Dunscroft Practice showed no signs of feigning sickness during the fortnight they were on strike; indeed the picture was that they demanded less medical time when no longer faced with mining work. 
We wish to thank Professor J. Knowelden for encouragement and advice. We are indebted for clerical help to Mrs. M. Julian, S.R.N., Mrs. L. Holgate, S.R.N., Mrs. P. Holgate, S.E.N., Mrs. N. Outram, S.R.N. and Mrs. K. Letton, S.R.N., secretary of the Hatfield Dunscroft Practice, also to Miss M. Beddard, Miss J. Pickering, Miss J. Rhodes, and Mrs. M. Tinsley of the Department of Preventive Medicine, Sheffield University.

\section{References}

Carne, S. (1969). Sick absence certification. Analysis of one group practice in 1967. Brit. med J., 1, 147-149.

Department of Health and Social Security (1969). Annual Report for 1968, pp. 251-252. (Cmnd. 4100). H.M.S.O., London.
Fay, S. (1969). The sick-pay strikers of Cardiff. Labour Correspondent, Sunday Times Business News. Article, 16 November, p. 25.

Lunn, J. E., Rider, J. G., Waters, W. H. R., and Charnock, R. B. (1970). Certification of unfitness for work in a mining area practice. J. roy. Coll. gen. Practit., 19, $215-222$.

Rider, J. G., Waters, W. H. R., Charnock, R. B., and Lunn, J. E. (1969). A study of workload in a mining area practice. J. roy. Coll. gen. Practit., 17, 361-369.

Stevenson, J. S. K. (1969). Senior Lecturer, General Practice Unit, Edinburgh University. A check on sick-pay strikers. Correspondence. Sunday Times. 23 rd November, 1969, p. 8.

Taylor, P. J., and Pocock, S. J. (1969). Post-war trends in sickness absence and unemployment in Great Britain. Lancet, 2, 1120-1123.

Received for publication January 17, 1970.

\section{The July (1970) Issue}

Short-term absence from industry. I. Literature, definitions, data, and the effect of age and length of service P. FroggatT

Short-term absence from industry. II. Temporal variation and inter-association with other recorded factors P. FrogGatT

An epidemiological study of respiratory symptoms in Lancashire mills, 1963-66 M. K. B. MoLYNEUX and J. B. L. TOMBLESON

Occupational asthma and rhinitis due to Western red cedar (Thuja plicata) with special reference to bronchial reactivity BRYAN GANDEVIA and JAMES MILNE

Influence of surgery for peptic ulcer on pneumoconiosis and tuberculosis T. J. G. PHILLIPS

Effect of general dietary deficiency and protein malnutrition on the fibrogenesis caused by silica dust in rats S. H. ZAIDI and J. L. KAW

Effect of ear-defenders (ear-muffs) on the localization of sound G. R. C. ATHERLEY and W. G. NOBLE

Circadian rhythms of body temperature in shift-workers at a coalface W. P. CoLQUHOUN and R. S. EDWARDS

Neuromuscular function in pesticide workers K. W. JAGER, D. V. ROBERTS, and A. WILSON

Occupational exposure to aldrin: clinical and laboratory findings P. AvAR and G. CzEGLÉDI-JANKó

Occupational exposure to lindane: clinical and laboratory findings G. CzEgLÉDI-JANKó and P. AvAr

Erythrocytes of uranium miners: the activity of the pentose phosphate pathway Z. Vích, F. NovosAD, and V. BRYCHTOVÁ

Book reviews

A number of copies are still available and may be obtained from the Publishing Manager, British Medical Association, Tavistock Square, London WC1H 9JR price 22s. $6 d$. 